\title{
ANU RADIOCARBON DATE LIST I
}

\section{H. A. POLACH, ${ }^{*}$ J. J. STIPP,* J. GOLSON** and J. F. LOVERING*}

Australian National University, Canberra, Australia

The Radiocarbon Dating Laboratory is installed in the Department of Geophysics and Geochemistry, Institute of Advanced Studies of the Australian National University. The Australian Institute of Aboriginal Studies has materially aided the establishment of the laboratory and is allocated a major proportion of the dating time over the next three years for samples in Australian Aboriginal archaeology. Beyond this the laboratory is to serve research needs within the University. To facilitate communication between collectors and laboratory a handbook on collection of specimens and interpretation of results has been prepared (Polach and Golson, 1966) and a radiocarbon sample record and an age determination sheet are in use.

Both methane gas counting and benzene liquid scintillation counting techniques are used in this laboratory.

For gas counting CDL-14 carbon-dating equipment was purchased from and installed by Beckman-Sharp in July 1965. Two detectors mounted within one multiple-anode guard ring are surrounded by 10 $\mathrm{cm}$ of boric acid and $10 \mathrm{~cm}$ of lead shielding. The two-energy-channel electronics are duplicated to allow simultaneous two-detector operation with automatic recording of all functions at preselected intervals (Sharp and Ellis, 1966). Dating started in April 1966 with preamplifiers and detectors redesigned in this laboratory and continued until July 1966, at which time it was interrupted to allow the installation and testing of new Beckman-Sharp preamplifiers. Dating resumed in September 1966.

Only one detector is operated for sample age determinations. It is of $0.5 \mathrm{~L}$ vol at STP and is filled for routine operations to 2 atm of purified $\mathrm{CH}_{4}(4.0 \mathrm{KV})$. The background is nominally 2 counts $/ \mathrm{min}$ and the net oxalic-acid standard rate is $7 \mathrm{cpm}$, giving a useful age range of up to $35,000 \mathrm{yr}$. The second detector situated within the guard has been used for continuous background monitoring since dating resumed in September 1966.

The methane preparation method used is similar to that described by Fairhall et al. (1961) with an additional radon purification step (Kruegers, pers. commun., 1966). Full details of the synthesis technique and apparatus are described by Polach and Stipp (1967). It is proposed to increase the working pressure of the sample detector to 5 atm (aprox. TVK). Tests carried out in this laboratory have shown Sprague $30 \mathrm{KV}$ ceramics to be suitable high voltage holding and filtering capacitors which remain noise-free up to $9 \mathrm{KV}$ (ca. 8 atm operation).

\footnotetext{
* Department of Geophysics and Geochemistry

** Department of Anthropology
} 
For liquid scintillation counting Stipp built in August 1966 a chemical line closely resembling the benzene synthesis system at Florida State University (Noakes et al., 1965). The synthesis technique used follows Barker's (1963) $\mathrm{CO}_{2}$ reaction with lithium with the significant change that only $10 \%$ excess $\mathrm{Li}$ is required, still maintaining a $98 \%$ acetylene yield. For the final acetylene-to-benzene synthesis activated vanadium catalyst is used (Noakes et al., 1965) and the overall yield approaches 95\% from sample carbon to counting-vial carbon. The production technique developed here and the equipment are described in detail by Polach and Stipp (1967).

The actual age determinations were carried out on a Packard model 3950 and a Beckman model 1650 liquid scintillation spectrometer. The $5-\mathrm{ml}$ vials used were prepared from standard 20-ml glass vials and are mounted on black ebonite bases. Background is ca. 8 counts/min and the oxalic-acid standard net rate is 30 counts with an efficiency of ca. $70 \%$, giving a useful dating range of ca. 35,000 yr. A normal sample for counting is $4 \mathrm{ml}$ benzene plus $1 \mathrm{ml}$ toluene with the appropriate PPO and POPOP scintillators.

The samples being currently dated are all either charcoal or wood and corrections for $\mathrm{C}^{13} / \mathrm{C}^{12}$ ratio are not necessary. However, reproducibility of the oxalic-methane preparation has been tested mass-spectroscopically by comparing $\mathrm{C}^{13} / \mathrm{C}^{12}$ ratios of 3 consecutive preparations. The results were within the limits of accuracy of the available equipment, namely $\pm 2 \%$. Our technique of oxalic- $\mathrm{CO}_{2}$ preparation follows closely the wet combustion used by Rafter (pers. commun., 1965) which normally yields $\mathrm{CO}_{2}$ with $\delta \mathrm{C}^{13}=-19 \%$, the value stipulated by Craig (1961) for $\mathrm{C}^{14}$ dating work. Reproducibility of the benzene preparation has been checked by directly comparing our count rates of oxalic-benzene samples with samples supplied for test purposes by 3 other laboratories. Within statistical counting limits all yielded the same count rate per gram of sample in the same machines. This study, which will be reported in detail elsewhere, enabled us to achieve routine operations with benzene in a matter of two weeks. Thus the dating with liquid scintillation counters coincided with the second gas counting period (Sept.-Nov. 1966), characterized by continuous background monitoring as mentioned previously.

Sample preparation is preceded by very careful visual separation and cleaning. This is followed in all cases with an acid wash, but the alkali treatment to remove humic acid contaminants is applied only where indicated by conditions of burial and only if sample size permits. Individual treatment is not described in the date list, but is reported directly to the collector along with the dates obtained.

Ages are calculated using the Libby half life of $5568 \mathrm{yr}$ and errors listed include errors in the determination of count rate of the modern standard, background and sample. The error is reported in terms of 1 standard deviation. The background and modern standard rates were 
averaged over the individual counting periods (2 April-27 June and 1 Sept.-9 Nov. 1966) but errors applied to the samples were computed from 4000-min background and 3000-min modern count rates only. Calculated errors of less than $100 \mathrm{yr}$ have been increased to that figure as a minimum. Some samples were counted several times or counted in all 3 machines as internal cross checks upon the validity of our age determinations. Also the known-age samples were bracketed between the unknowns at regular intervals to guard against any undetected interference.

Interference with counting operations and low-background determinations has occurred due to the operation by the Nuclear Physics Department, A.N.U., of a Van de Graaf Tandem Accelerator. An increase in background rate from the normal 2 counts/min value up to 3 to 5 counts/min was correlated with the detection of fast neutrons, produced when deuterons were accelerated above $6 \mathrm{MeV}$ energy. This increase was readily monitored by the second gas dectector, and interruption of dating operations was confined to the interference period. The data accumulated during the periods of interference are being currently analyzed and the mechanism of pick-up, shielding requirements, and the possibility of application of a correction factor are being assessed in a paper not yet submitted for publication (Polach and Stipp, 1966).

\section{ACKNOWLEDGMENTS}

We wish to acknowledge the contributions made by Mr. G. R. Graf and Mr. M. Trotman from the Electronics section of the Research School of Physical Sciences, who were responsible for the pre-amplifier design and who carried out modifications and maintenance of the electronics; Dr. W. G. Laver and Dr. M. Simpson-Morgan for permission to carry out liquid-scintillation measurements in their departments of the John Curtin School of Medical Research, A.N.U.; Mrs. J. Harris, University of New South Wales Radiocarbon Dating Laboratory, for mass-spectrometric determinations; Dr. Meyer Rubin, U.S. Geological Survey, Washington, D.C., T. A. Rafter, Institute of Nuclear Sciences, N.Z., G. A. M. Taylor, Bureau of Mineral Resources, Canberra, and D. J. Mulvaney, Department of Anthropology, A.N.U., who supplied us with alreadydated material; Mr J. Angus, Department of Geophysics, A.N.U., for help with the installation of the laboratory.

Our particular thanks go to Dr L. L. McDowell, U.S.D.A., Oxford, Mississippi, for donation of benzene vanadium catalyst and oxalicbenzene samples, and Dr. J. Pearson and R. Wiggins, University of Texas, and G. Knauer, Florida State University, for supply of dated material as well as oxalic-benzene samples.

The following list reports $80 \%$ of the determinations made during the counting periods specified above. The total counting time for each sample is noted. Methane means gas-proportional counting, benzene means liquid-scintillation counting. 


\section{SAMPLE DESCRIPTIONS}

\section{CHECK SAMPLES}

TABLE 1

Interlaboratory cross checks

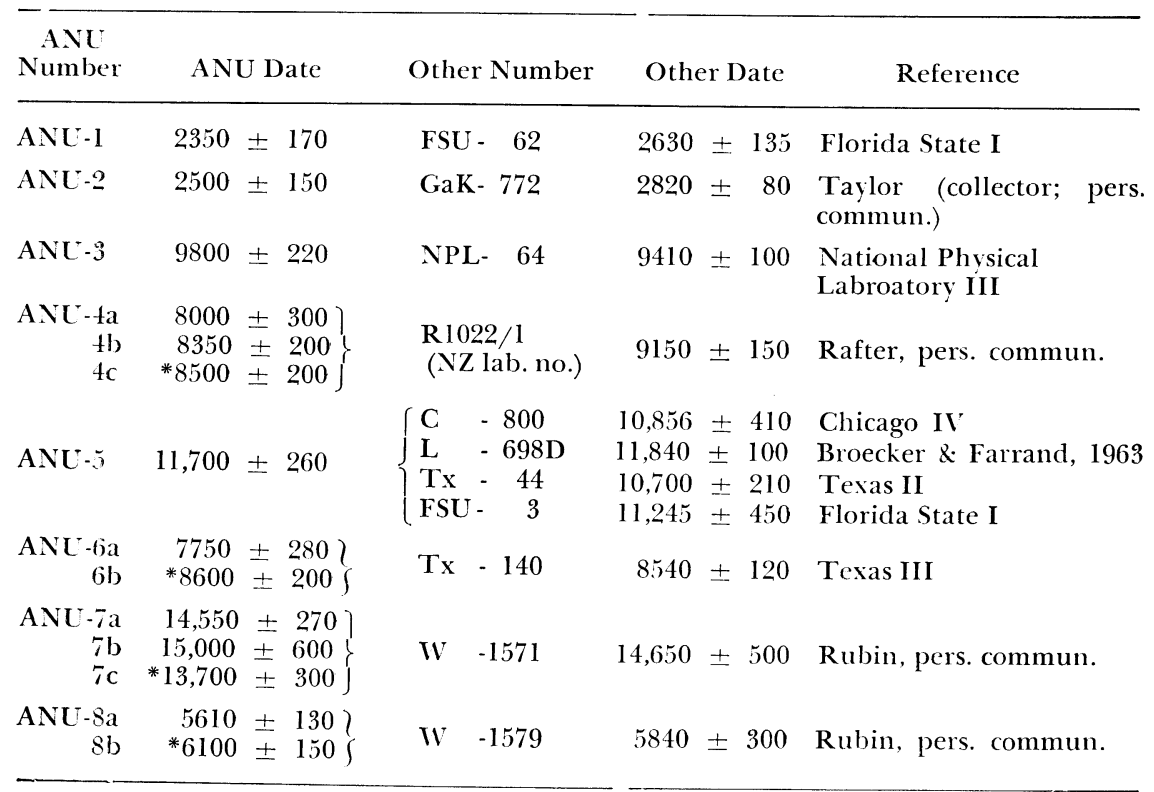

* Benzene-liquid scintillation determinations.

Comment (H.A.P.) : the table records satisfactory agreement with other laboratories in respect of both methods employed at A.N.U. The only real exceptions are ANU ta to c, a discrepancy which is to be investigated.

TABLE 2

Methane gas-proportional and Benzene liquid-scintillation cross checks

\begin{tabular}{lrr}
$\begin{array}{c}\text { ANU } \\
\text { Number }\end{array}$ & Methane Date & Benzene Date \\
\hline ANU-4 & $\left\{\begin{array}{r}8000 \pm 300 \\
8350 \pm 200\end{array}\right.$ \\
ANU-6 & $7750 \pm 280$ & $8500 \pm 200$ \\
ANU-7 & $\{14,550 \pm 270$ & $13,700 \pm 300$ \\
$15,000 \pm 600$ & $6100 \pm 150$ \\
ANU-8 & $5610 \pm 130$ & $31,000 \pm 1000$ \\
ANU-9 & $32,000 \pm 3200$ & $3100 \pm 100$ \\
ANU-17 & $3140 \pm 110$ & \\
\hline
\end{tabular}

Comment (H.A.P.) : each date listed represents an individual synthesis. The agreement is excellent. Details of ANU-9 and 17 are in the date list, ANU-4 to 8 are also interlaboratory cross checks listed in Table 1 . 
TABLE 3

Methane gas-proportional counting-period cross checks

April-June and Sept.-Nov. 1966

\begin{tabular}{lrr}
\hline ANU & $\begin{array}{c}\text { Methane I } \\
\text { April-June }\end{array}$ & $\begin{array}{l}\text { Methane II } \\
\text { Sept.-Nov. }\end{array}$ \\
\hline ANU-7 & $15,000 \pm 600$ & $14,550 \pm 300$ \\
ANU-27 & $2040 \pm 120$ & $2250 \pm 150$ \\
ANU-28 & $8500 \pm 500$ & $9950 \pm 300$ \\
\hline
\end{tabular}

Comment (H.A.P.): methane samples stored in stainless steel cylinders. Agreement in countrate is excellent showing that modifications to equipment did not affect its reliability and that radon removal procedures are adequate. ANU-28 is held over for publication and does not appear in this date list.

\section{GEOLOGIC SAMPLES}

\section{A. New Guinea}

\section{Kosipe, Central District, Papua}

See ANU-21.

\section{B. New Zealand}

\section{ANU.9. Manukau Harbour, Mangere, Auckland $\quad 29,050$ в.c.}

Wood from fossil forest exposed on shore platform beneath bedded tuffs covered by lavas from Ihumatao (Maungataketake) cone $\left(37^{\circ} 00^{\prime} \mathrm{S}\right.$ Lat, $174^{\circ} 45^{\prime}$ E Long). Sample from same context, coll. by E. J. Searle, Univ. of Auckland, has been dated to 29,000 \pm 1500 (27,050 в.C.), NZ215 (Searle, 1959). Purpose of recollection was to confirm maximum radiocarbon age of basalt for use in possible cross checking by potassiumargon dating. Coll. Oct. 1965 and subm. by J. J. Stipp, A.N.U. Methane, 3-day count 32,000 \pm 3200 . Benzene, 2-day count 31,000 \pm 1000 . Comment (J.J.S.): determinations confirm NZ-215.

\section{ARCHAEOLOGIC SAMPLES}

\section{A. Australia}

\section{Lapstone Creek series, New South Wales}

Lapstone Creek sandstone rockshelter, ca. $35 \mathrm{mi}$ W of Sydney on $\mathrm{E}$

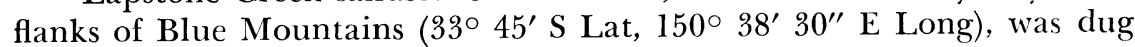
in 1936 and reported in 1948. With maximum depth of deposit of 55 in., it provided first stratified sequence of industries in Australia $\mathrm{E}$ of Dividing Range. On it McCarthy (1948) based his division of later eastern New South Wales prehistory into an earlier Bondaian and a later Eloueran phase. McCarthy's picture has been amplified and refined by later work, for which there are a number of radiocarbon dates available, particularly for Bondaian phase (McCarthy, 1964; McBryde, 1965; Megaw, 1965, 1966; Gakushuin V, GaK-564 to 572; Victoria I, V-10 and 
11,24 to 26,33 to 36,39 to 45 ). It is interesting now to have dates for this important type site. Samples collected in glass bottles by F. D. McCarthy on occasion of original excavations in Dec. 1936. Subm. by Australian Inst. of Aboriginal Studies.

\section{ANU-10. Lapstone Creek, Section 3, 36 in. below surface \\ $3650 \pm 100$ 1700 B.C.}

Charcoal from homogeneous ash-rich deposit. In sec. 3 of excavation bondi points were distributed between $28 \mathrm{in}$. and $48 \mathrm{in}$. from surface. Sample therefore should date a midpoint in Bondaian occupation. Benzene, 2-day count. Comment (F.D.McC.): date falls early in time range presently established by radiocarbon dating for Bondaian in eastern N.S.W.

\section{ANU-11. Lapstone Creek, Section 3, 20 in. from surface \\ $2300 \pm 100$ 350 B.C.}

Charcoal from homogeneous ash-rich deposit. In Sec. 3 of excavation elouera were distributed between 7 in. and 30 in. depth. Sample should date therefore just before midpoint of Eloueran occupation. Benzene, 2-day count. Comment (F.D.McC.): this seems an early date for disappearance of bondi points. At Curracurrang, also in immediate Sydney district, Megaw (1965) has a date, I-1135, $1580 \pm 130$ (A.D. 370), for a midpoint in Bondaian layer. Northern N.S.W. bondi points persist well into present millennium (Gakushuin V, GaK-569 to 572).

\section{ANU-12. Sandy Hollow rockshelter, Hunter $\quad 1300 \pm 100$ Valley, New South Wales \\ A.D. 650}

Charcoal from $23 \mathrm{in}$. to $24 \mathrm{in.} \mathrm{depth} \mathrm{just} \mathrm{inside} \mathrm{dripline} \mathrm{of} \mathrm{small}$ rockshelter in upper Hunter Valley (32० $21^{\prime} \mathrm{S}$ Lat, $150^{\circ} 33^{\prime} \mathrm{E}$ Long). At deepest, cultural materials extend to $3.5 \mathrm{ft}$. They consist of cooking and workshop waste and artefacts of Bondaian cultural type. Sample dates midpoint of deposit and the most prolific horizon. Coll. Mar. 1966 by D. R. Moore, Australian Mus., Sydney; subm. by Australian Inst. of Aboriginal Studies. Benzene, 3-day count. Comment (D.R.M.): date falls in later part of Bondaian phase in eastern New South Wales and may be compared with dates reported for Miss McBryde's excavations in New England 200 mi N (McBryde, 1965; Gakushuin V, GaK-564 to 572; Victoria I, V-10 and 11,24 to 27,39 to 45 ).

\section{ANU-13. Durras, North, South Coast, New South Wales \\ $680 \pm 160$ \\ A.D. 1270}

Charcoal from thin occupation horizon in sand, $85 \mathrm{~cm}$ below ground surface and $25 \mathrm{~cm}$ above bedrock sandstone, adjacent to $\mathrm{N}$ shore of coastal lagoon (Durras Lake) and near its mouth $\left(35^{\circ} 38^{\prime} 30^{\prime \prime} \mathrm{S}\right.$ Lat, $150^{\circ}$ $18^{\prime} 10^{\prime \prime} \mathrm{E}$ Long). Two edge-ground axes came from same horizon, which is at about present lake level. Coll. Aug. 1965 by R. J. Lampert, A.N.U.; subm. by Australian Inst. of Aboriginal Studies. Benzene dilution, 1-day 
count. Comment (R.J.L.): date is close to that for earliest occupation of sea cave $1 \mathrm{~km} \mathrm{~N}$ along beach, GaK-873, $480 \pm 80$ (A.D. 1470) (Lampert, 1966).

\section{ANU-14. Platform Gallery rockshelter $\quad 6120 \pm 150$ Cooktown, Queensland \\ 4170 B.c.}

Charcoal from $10.5 \mathrm{ft}$. depth in sandstone rockshelter ca. $20 \mathrm{mi} \mathrm{NW}$ of Cooktown (15 $14^{\prime}$ S Lat, $145^{\circ} 4^{\prime}$ E Long). Sample dates first appearance of cultural material at site in form of a single chalcedonic flake. Excavation was continued through sterile deposit to depth of $12 \mathrm{ft}$. Coll. Apr. 1965 by F. P. Woolston; subm. by Australian Inst. of Aboriginal Studies. Benzene, 2-day count. Comment (F.P.W.): will be valuable for comparison with major excavation carried out by R. V. S. Wright, Univ. of Sydney, at Laura shelter in same region.

\section{Yarar series, Port Keats, Northern Territory}

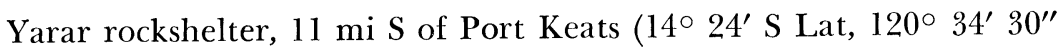
E Long), was excavated in 1958 by W. E. H. Stanner, A.N.U., and produced over a depth of ca. 27 in. a rich stone-point industry which was analyzed in 1966 by Mrs. J. M. Flood, A.N.U. Samples coll. 1958 by Stanner; subm. by Australian Inst. of Aboriginal Studies.

\section{ANU-15. Yarar rockshelter, Square 2J,} 6 in.-12 in. deep

$450 \pm 100$

\section{A.D. 1500}

Charcoal dating period of maximum occupation of shelter, with large numbers of unifacial and bifacial points and lowest occurrence of edge-ground axes at site. Methane, 1-day count.

\section{ANU-16. Yarar rockshelter, Square 2J, $\quad 1620 \pm 100$} 18 in.-24 in. deep

A.D. 330

Charcoal dating early stage in occupation of site, with a point industry similar to higher level. Methane, 2-day count.

Comment (J.M.F.): both age estimations fall within expectation, ANU16 may be compared with date for a comparable industry at Ingaladdi, 125 mi SE, GX-103, $1545 \pm 75$ (A.D. 405) (Geochron I).

\section{ANU-17. Padypadiy rockshelter, Oenpelli, $\quad 3120 \pm 100$ Northern Territory \\ 1170 B.C.}

Charcoal on bedrock at base of shell midden forming earlier phase of occupation in rockshelter in sandstone residual on plains $4.5 \mathrm{mi} \mathrm{W}$ of East Alligator River and $12.5 \mathrm{mi} \mathrm{SW}$ of Oenpelli Mission $\left(12^{\circ} 26^{\prime} \mathrm{S}\right.$ Lat, $132^{\circ} 54^{\prime}$ E Long). Sample will provide maximum age for jaw fragment of Tasmanian devil (Sarcophilus harrisi) found in same midden 4 $\mathrm{cm}$ above bedrock, 20 to $25 \mathrm{~cm}$ below surface of deposit. This is first find of Tasmanian devil in tropical Australia. Coll. July 1965 by Carmel White, A.N.U.; subm. by Australian Inst. of Aboriginal Studies. Date is average of two determinations: methane, 3-day count, $3140 \pm 110$, ben- 
zene 2-day count, $3100 \pm 100$. Comment (C.W.): find extends range for Tasmanian devil to tropical Australia and date shows its relatively recent persistence there.

\section{ANU-18. Tyimede (Jeemeri) 2, Oenpelli, $\quad 6650 \pm 500$ Northern Territory \\ 4700 B.c.}

Charcoal specks from remains of hearth (?) in greyish brown sand 60 to $70 \mathrm{~cm}$ from surface of deposits at mouth of large waterworn cavern in sandstone in valley in Arnhem Land escarpment $14 \mathrm{mi} \mathrm{E} 20^{\circ} \mathrm{S}$

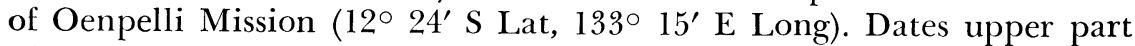
of a scraper and ground-axe industry, which extends from 60 to $80 \mathrm{~cm}$ below surface of deposit and underlies a bifacial point industry extending from 0 to $50 \mathrm{~cm}$ below surface. Coll. Oct. 1965 by Carmel White; subm. by Australian Inst. of Aboriginal Studies. Methane dilution with dead gas, 2-day count. Comment (C.W.): the date conflicts with GaK-632, $10,790 \pm 200$ (8840 B.C.), for early stage of bifacial point industry at Tyimede 1, a rockshelter $300 \mathrm{ft} \mathrm{N}$, (120 24' S Lat, $133^{\circ} 15^{\prime}$ E Long, revised position) (Gakushuin V). Because of this and problems discussed under ANU-19 below, further dating needed.

\section{ANU-19. Malangangerr rockshelter, Oenpelli, $\quad 18,000 \pm 400$ Northern Territory \\ 16,050 в.c.}

Charcoal from remains of hearth (?) in yellowish brown sand 104 to $114 \mathrm{~cm}$ from surface of deposit in rockshelter in a detached block of sandstone on plains $11 \mathrm{mi} \mathrm{SW}$ of Oenpelli Mission and $0.5 \mathrm{mi} \mathrm{W}$ of East Alligator River (12० $27^{\prime} \mathrm{S}$ Lat, $132^{\circ} 57^{\prime} \mathrm{E}$ Long). Associated with scraper and ground-axe industry distributed from 60 to $180 \mathrm{~cm}$ depth in area of collection and overlain by bone and bifacial stone point industry in shell midden. Sample was submitted to investigate archaeological problem raised by GaK-628 (150 to $154 \mathrm{~cm}$ in deposit), 19,600 \pm 550 (17,650 в.c.), and GaK-629 (138 cm deep), 22,700 \pm 700 (20,750 B.c.), which gave surprisingly old ages for ground-stone axes in Australia (Gakushuin V). Coll. Aug. 1965 by Carmel White; subm. by Australian Inst. of Aboriginal Studies. Methane, 2-day count. Comment (C.W.): ANU-19 confirms GaK-628 and 629 on antiquity of charcoal samples and archaeological problem remains. Geomorphological and archaeological work at site subsequent to receipt of dates confirmed in situ position of stone axes and revealed no process whereby old carbon could have contaminated the site.

\section{B. New Guinea}

ANU-20. Kafiavana rockshelter, southern Asaro valley, Eastern Highlands District

Charcoal from 250 to $270 \mathrm{~cm}$ depth in deposit in calcareous siltstone rockshelter, $12 \mathrm{mi} \mathrm{S} 15^{\circ} \mathrm{E}$ of Goroka, alt ca. $4500 \mathrm{ft}\left(6^{\circ} 14^{\prime} \mathrm{S} \mathrm{Lat,} 145^{\circ}\right.$ 
$25^{\prime}$ E Long). Cultural materials occur to depth of $380 \mathrm{~cm}$ and in two main concentrations, at 20 to $120 \mathrm{~cm}$ and 210 to $300 \mathrm{~cm}$. Fragments of ground-stone tools occur deeper than $300 \mathrm{~cm}$. Charcoal scarce throughout site and ANU-20 is combination of three small collections of carbon spicules from three adjacent square-metre excavation units. Coll. Apr. 1965 and subm. by J. P. White, A.N.U. Benzene dilution, 2-day count. Comment (H.A.P.): sample was very small, yielding only $0.18 \mathrm{~g}$ of benzene, but because of its importance to archaeologist, attempt was made to give at least the measure of antiquity of the sample. Age is consequently reported as not younger than 9500 with a $95 \%$ probability. Comment (J.P.W.): this indication that a ground-stone technology was present in Highlands by 9500 B.P. should be compared with Mrs. Bulmer's results from Kiowa rockshelter at Chuave, $21 \mathrm{mi}$ NW of Kafiavana. Here appearance of ground axes is bracketed by Y-1370, $6100 \pm 160$ (4150 B.C.), and Y-1317, $4840 \pm 140$ (2890 B.C.) (Bulmer, 1964). Samples of animal bone from immediately above and below ANU-20 have been submitted for dating.

\section{$\begin{array}{ll} & 4050 \pm 500 \\ \text { ANU-21. Kosipe, Central District, Papua } & 2100 \text { B.c. }\end{array}$}

Charcoal from site on sloping crest of a spur, alt ca. $6100 \mathrm{ft}$, at Kosipe Mission, $11 \mathrm{mi}$ NNW of Woitape Govt. Station, Central Dist., Papua $\left(8^{\circ} 30^{\prime} \mathrm{S}\right.$ Lat, $147^{\circ} 20^{\prime}$ E Long). Sample occurred as scattered lumps in $\mathrm{B}$ horizon of a soil developed from volcanic ash fall overlying older, more weathered volcanic ash with similar soil profile. From this older ash mortars, waisted blades and ground stone axes have been recovered (White, 1965). Older ash is dated by GaK-624, 16,300 \pm 1200 (15,350 B.C.), and GaK-625, 19,350 \pm 600 (17,400 B.c.) (Gakushuin IV); dates also provide maximum age for artefacts. ANU-21, taken ca. $4 \mathrm{~m} \mathrm{~W}$ of GaK-625, provides minimum age for younger ash fall and artefacts beneath it. Coll. Aug. 1966 by K.A.W. Crook (Geology); subm. by J. P. White (Anthropology), A.N.U. Benzene dilution, 1-day count. Comment (J.P.W. and K.A.W.C.): Kosipe series provides first dates for mortars in New Guinea. Earliest waisted blades at Mrs. Bulmer's Kiowa site in Eastern Highlands District are bracketed by Y-1370 and Y-1371 (see comment on ANU-20). Two volcanic ashes are believed to derive from Mt. Lamington and may represent two of ash showers described by Ruxton (1966). Mineralogical investigations into question are proceeding.

\section{Oceania}

\section{ANU-22. Te Aka village site, Ocean Island Modern $<200$}

Partly carbonized wood from post of earliest building phase of sequence of four excavated on site of maneaba (meeting house) at $\mathrm{Te}$ Aka village site $\left(0^{\circ} 51^{\prime} 50^{\prime \prime} \mathrm{S}\right.$ Lat, $169^{\circ} 35^{\prime} 15^{\prime \prime} \mathrm{E}$ Long). Coll. Feb. 1965 and subm. by R. J. Lampert, A.N.U. Wood penetrated by roots which 
were carefully removed before dating. Benzene, 1-day count. Comment (R. J. L.): as there is evidence for village buildings still standing early this century, modern date for previous phase of village is not altogether surprising.

\section{Tongatapu series, Tonga}

Two samples from a series collected by J. I. Poulsen, A.N.U., in the course of archaeological fieldwork on Tongatapu in 1963-4. Four major sites were excavated, Tonga 1, 2, 5 and 6 , in the main refuse dumps with abundant shell and pottery but little charcoal. Dates available are:

$\begin{array}{lrrrlll}\text { K-904. } & 2770 \pm 100 & (820 \quad \text { B.C. } & \text { shell } & \text { Tonga } 1 \\ \text { K-961, } & 420 \pm 100 & \text { (A.D. 1530) } & \text { charcoal } & \text { Tonga 1 } \\ \text { NZ-597, } & 464 \pm 82 & \text { (A.D. 1486) } & \text { charcoal } & \text { Tonga } 1 \\ \text { NZ-635, } & 1620 \pm 60 & \text { (A.D. } 330) & \text { charcoal } & \text { Tonga } 2 \\ \text { NZ-636, } & 2380 \pm 51 & (430 & \text { B.C. }) & \text { charcoal } & \text { Tonga } 6 \\ \text { NZ-637, } & 1600 \pm 87 & \text { (A.D. } 350) & \text { charcoal } & \text { Tonga } 5\end{array}$

Coll. Aug. 1964; subm. by J. I. Poulsen.

\section{ANU-23. Tonga 5, near Veitongo village A.D. 1620}

$330 \pm 100$

Charcoal from fire hollow $\mathrm{D}, 30 \mathrm{~cm}$ below surface of midden $1 \mathrm{~m}$ deep, $150 \mathrm{~m}$ from lagoon and ca. $1.5 \mathrm{~m}$ above its level $\left(21^{\circ} 1 \mathrm{l}^{\prime} \mathrm{S}\right.$ Lat, $175^{\circ} 13^{\prime}$ E Long). Should date later than NZ-637 from fire hollow B which is stratigraphically earlier, and by evidence of associated pottery styles should be of same order of age as upper levels of Tonga 1, that is later than K-961 and NZ-597. Methane, 3-day count. Comment (J.I.P.): date is in excellent agreement with the other evidence and marks late stage in development of Tongan prehistoric pottery.

\section{ANU-24. Tonga 6, near Pea village}

$2350 \pm 200$

Charcoal from fire hollow DN, in clay subsoil 90 to $100 \mathrm{~cm}$ from ground surface at base of midden, which lies on edge of raised coral just above Pea village (21 $10^{\prime} 20^{\prime \prime} \mathrm{S}$ Lat, $175^{\circ} 14^{\prime} 20^{\prime \prime} \mathrm{E}$ Long). Pottery from site suggested that it belonged to late phase of Tongan prehistory, its lower levels equivalent to upper levels at Tonga 1 and Tonga 5 (see ANU-23). However NZ-636 from fire hollow K, dug into clay subsoil $1 \mathrm{~m}$ from present sample, gave much earlier date. Methane, l-day count. Comment (J.I.P.): ANU-24 confirms NZ-636. Both dated fire hollows are in corner of excavated area at Tonga 6 and appear to belong to very early phase of occupation only just touched by excavations. Some of material excavated at site can tentatively be attributed to this early phase, which however stands prior to any stage of pottery sequence established by excavation for Tongatapu. 
D. New Zealand

\section{Kauri Point series, North Island}

Kauri Point $p a$ (fortified settlement), N53-54/5 in NZ Archaeol. Assoc. site records, is on small peninsula into Tauranga Harbour, western

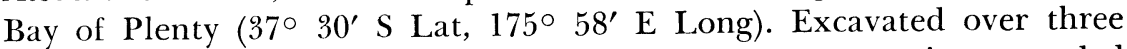
seasons 1960-3 (Golson et al., 1961; Ambrose, 1962). Excavations revealed evidence of multiphased occupation, with latest ditch and bank defences enclosing smaller area than the earliest.

\section{ANU-25. Kauri Point $\mathbf{N}$ defences}

$495 \pm 100$

Charcoal from layer of food refuse lying on artificial terrace and overlain immediately and without weathering interval by upcast from first of defensive ditches at site. Sample should therefore closely date construction of ditch. Coll. Jan. 1963; subm. by W. R. Ambrose, A.N.U. Date is average of two 1-day methane counts: $410 \pm 110$ and $580 \pm 110$.

ANU-26. Kauri Point, Structure B, Squares L29/30

$230 \pm 100$

\section{A.D. 1720}

Charcoal from fire hollow (? hearth) in floor of sunken rectangular pit on lowest of series of terraces within earliest defensive circuit but outsicle subsequent ones. For this reason expected to date close to ANU25. Coll. Jan. 1961; subm. by W. R. Ambrose. Methane, 1-day count. Comment (W.R.A.): ANU-25 accords well with sample from associated site (Shawcross, 1962; 1963) in adjacent swamp: $398 \pm 56$ (A.D. 1552), NZ intralaboratory reference R 1418/1 (F. W. Shawcross, pers. commun.). ANU-26 is unexpectedly young in respect to ANU-25 and may indicate that structure $\mathrm{B}$ is later than terrace into which it is dug.

\section{E. Malaya}

\section{ANU-27. Kampong Sungai Lang}

$2145 \pm 100$

195 B.C.

Wood from site in mangrove swamps on lot 1670 at this village, Mukin Kelanang, Kuala Langat district, Selangor $\left(2^{\circ} 45^{\prime} \mathrm{N}\right.$ Lat, $101^{\circ}$ $30^{\prime}$ E Long), associated with Dongson metal work. Coll. 1964 by B. A. V. Peacock, Univ. of Malaya; subm. by J. Golson, A.N.U. Date is average of two determinations: methane, 2-day count, period April to June 1966, $2040 \pm 120$, and methane, 2-day count, period Sept. to Nov., $2250 \pm 150$. Comment (J.G.): two other date are available:

$$
\begin{aligned}
& \text { GaK-684 1850 } \pm 90 \text { (A.D. 100) on part of same sample as } \\
& \text { ANU-27 } \\
& \text { GX-280 } 2435 \pm 95 \quad \text { (485 } \quad \text { B.c.) on sample from same site }
\end{aligned}
$$

On the whole dates tend to be somewhat older than would be expected on historical grounds. Dongson is contemporary, at least in part, with 
Han dynasty (roughly 200 B.C.-A.D. 200) in its home regions (S. Chína, N. Vietnam) and its Malayan manifestations might be reasonably supposed to postdate this.

Date lists:

Chicago IV

Florida State I

Gakushuin V

Geochron I

National Physical Laboratory III

Texas II

Texas III

Victoria I

\section{REFERENCES}

Libby, 1954

Stipp, Knauer and Goodell, 1966

Kigoshi and Kobayashi, 1966

Krueger and Weeks, 1965

Callow, Barker and Hassall, 1965

Tamers, Pearson and Davis, 1964

Pearson et al., 1965

Bermingham, 1966

Ambrose, W. R., 1962, Further investigations at Kauri Point, Katakati: New Zealand Archaeol. Assoc. Newsletter, v. 5, p. 56-67.

Barker, H., 1953, Radiocarbon dating: large scale preparation of acetylene from organic material: Nature, v. 172, p. 631-632.

Bermingham, Anne, 1966, Victoria natural radiocarbon measurements I: Radiocarbon, v. 8 , p. 507-521.

Broecker, W. S., and Farrand, W. R., 1963, Radiocarbon age of the Two Creeks Forest Bed, Wisconsin: Geol. Soc. Am. Bull., v. 74, p. 795-802.

Bulmer, Susan, 1964, Radiocarbon dates from New Guinea: Jour. Polynesian Soc., v. 73, p. $327-328$.

Callow, W. J., Baker, M. J., and Hassall, Geraldine I, 1965, National Physical Laboratory radiocarbon measurements III: Radiocarbon, v. 7, p. 156-161.

Craig, H., 1961, Mass-spectrometer analyses of radiocarbon standards: Radiocarbon, v. 3 , p. $1-4$.

Fairhall, A. W., Schell, W. R., and Takashima, Y., 1961, Apparatus for methane synthesis for radiocarbon dating: Rev. Sci. Instruments, v. 32, p. 323-325.

Golson, J., Melvin, L. W., Pullar, W. A., and Schofield, J. C., 1961, Investigations at Kauri Point, Katikati, western Bay of Plenty: New Zealand Archaeol. Assoc. Newsletter, v. 4, p. 13-41.

Kigoshi, K., and Kobayashi, H., 1966, Gakushuin natural radiocarbon measurements V: Radiocarbon, v. 8, p. 54-73.

Krueger, H. W., and Weeks, C. F., 1965, Geochron Laboratories, Inc., radiocarbon measurements I: Radiocarbon, v. 7, p. 47-53.

Lampert, R. J., 1966, An excavation at Durras North, New South Wales: Archacol. and Phys. Anthropol. in Oceania, v. 2, p. 83-118.

Libby, W. F., 1954, Chicago radiocarbon dates IV: Science, v. 119, p. 135-140.

McBryde, Isabel, 1965, Radiocarbon dates for archaeological sites in the Clarence valley, northern New South Wales: Oceania, v. 35, p. 260-266.

McCarthy, F. D., 1948, The Lapstone Creek excavation: two culture periods revealed in eastern New South Wales: Recs. Australian Mus., v. 22, p. 1-34. 1964, The archaeology of the Capertee valley, New South Wales: Recs.
Australian Mus.,v. 26, p. 197-246.

Megaw, J. V. S., 1965, Excavations in the Royal National Park, New South Wales: a first series of radiocarbon dates from the Sydney district: Oceania, v. 35, p. 202-207. Hacking, N. S. W.: Archaeol. Hacking, N. S. W.: Archaeol. and Phys. Anthropol. in Oceania, v. 1, p. 23-50.

Noakes, J. E., Kim, S. M., and Stipp, J. J., 1965, Chemical and counting advances in liquid scintillation age dating: Internat. C-14 and H-3 Dating Conf., Pullman,
Washington, June 7-11, Proc.

Pearson, F. J., Jr., Davis, E. M., Tamers, M. A., and Johnstone, R. W., 1965, University of Texas radiocarbon dates III: Radiocarbon, v. 7, p. 296-314. 
Polach, H. A., and Golson, J., 1966, Collection of specimens for radiocarbon dating and interpretation of results: Canberra, Australian Inst. of Aboriginal Studies, Manual no. 2.

Polach, H. A., and Stipp, J. J., 1966, Neutron flux and its effect on radiocarbon dating equipment: an interim report: Canberra, Australian National Univ., Dept. Geophỵs. and Geochem.

1967, Improved synthesis technique for methane and benzene radiocarbon dating: Internat. Jour. Applied Radiation and Isotopes, in press.

Ruxton, B. P., 1966, Correlation and stratigraphy of dacitic ash-fall layers in NorthEast Papua, Jour. Geol. Soc. Australia, v. 31, p. 41-67.

Searle, E. J., 1959, The volcanoes of Ihumatao and Mangere, Auckland: New Zealand Jour. Geol. and Geophys., v. 2, p. 870-888.

Sharp, R. A., and Ellis, J. G., 1965, System design in low background internal gas sample counting of carbon-14 and tritium: Internat. C-14 and H-3 Dating Conf., Pullman, Washington, June $7-11$, Proc.

Shawcross, F. W., 1962, The Kauri Point swamp: New Zealand Archaeol. Assoc. Newsletter, v. 5, p. 51-55.

1963, Kauri Point swamp: an interim report: New Zealand Archaeol. Assoc. Newsletter, v. 6, p. 50-56.

Stipp, J. J., Knauer, G. A., and Goodell, H. G., 1966, Florida State University radiocarbon dates I: Radiocarbon, v. 8, p. 46-53.

Tamers, M. A., Pearson, F. J., Jr., and Davis, E. M., 1964, University of Texas radiocarbon dates II: Radiocarbon, v. 6, p. 138-159.

White, J. P., 1965, Archaeological excavations in New Guinea: an interim report: Jour. Polynesian Soc., v. 74 , p. 40-56. 